\title{
EXPERIMENTAL TESTING OF THE PEDAGOGICAL MODELLING OF THE PROFESSIONAL MILITARY ORIENTATION OF THE SECONDARY EDUCATION INSTITUTIONS OF A MILITARY PROFILE STUDENTS \\ ЕКСПЕРИМЕНТАЛЬНА ПЕРЕВІРКА ПЕДАГОГІЧНОГО МОДЕЛЮВАННЯ ВІЙСЬКОВО-ПРОФЕСІЙНОї ОРІЄНТАЦІЇ ЛІЦЕЇСТІВ ЗАКЛАДІВ СПЕЦІАЛІЗОВАНОЇ СЕРЕДНЬОЇ ОСВІТИ ВІЙСЬКОВОГО ПРОФІЛЮ
}

UDC 355.131 (477)

DOI https://doi.org/10.32843/2663$6085 / 2020 / 27.10$

\section{Yahupov V.V.,}

Doctor of Pedagogical Sciences,

Professor,

Professor at the Chair of Physical

Education, Special Physical Training and Sports

National Defence University of Ukraine named after Ivan Cherniakhovskyi

\section{Yerhidzei K.V.,}

Head of Scientific Research Laboratory of the Problems of Operational, Technical and Logistic Support Institute of the Troops (Forces) Support and Information Technologies of the National Defence University of Ukraine named after Ivan Cherniakhovskyi
The article describes the methodology and stages of conducting the experiment. It defines and attains the main objectives for the pedagogical modelling of the lyceum students' professional military orientation, namely the development and justification for a complex programme of the professional military orientation process effectivization based on its pedagogical modelling in lyceums; identification of the possibilities for correcting academic programmes enabling introduction of changes with the purpose of the realisation of a set of pedagogical conditions (influences and interactions) envisioned by the survey and aimed at the effectivization of the military lyceum students' professional military orientation; conducting of the pedagogical experiment; analysis and generalisation of the results attained, the evaluation of the effectiveness of the activities for the military lyceums students' professional military orientation. In order to conduct the experiment, a system of criteria and indicators was devised for diagnosing its results, according to which the assessment was made as to the effectiveness of pedagogical conditions influence on the students' professional military orientation: valuemotivational, cognitive, behavioural-actional and subjective criteria. The article describes the results of the experiment showing that the most effective pedagogical conditions for developing a motivation for professional military orientation are as follows: demonstration of the importance of the students' professional military orientation formed while mastering general educational and general military activities; activation of the students' learning and gnostic activity; formation of the students' interest in military activities; cultivation of students' confidence in the social significance of the military profession. It was discovered that the most rational method for the control of the experiment data validity is the study and analysis of the graduates' further professional military activity. The major indicators assessed in this case were the lyceum graduate's enrolment to higher military education institutions of the Armed Forces of Ukraine and their successful mastering of the programme while studying there.

Key words: professional military orientation, military lyceum, lyceum student, student, pedagogical conditions, motivation, learning and gnostic activity, experiment, results.

у статті описано методику проведення експерименту; описано етапи виконання дослідження. Визначенні та вирішувались основні завдання для педагогічного моделювання військово-профресійної орієнтації лічеїстів, а саме розроблення й обгрунтування комплексної програми з підвищення ефрективності процесу військово-професійної орієнтації на основі ії педагогічного моделювання в ліцеях; з'ясування можливостей коригування навчальних програм для внесення до них змін із метою реалізації передбаченого дослідженням комплексу педагогічних умов (впливів і взаємодій), спрямованих на підвищення результативності військовопрофессійної орієнтації у вихованців військових ліцеїв; проведення педагогічного експерименту; аналіз і узагальнення отриманих результатів, визначення результативності заходів щодо військово-профессійної орієнтації вихованців військових ліцеїв. Для проведення експериментальної роботи була розроблена система критеріїв та показників діагностування ії результатів, за якими оцінювалась результативність впливу педагогічних умов на військово-профессійну орієнтацію ліцеїстів: ціннісно-мотиваційний критерій, когнітивний, поведінково-діяльнісний та суб'єктний. у статmі описані результати експериментальної роботи, які показали, що найбільш ефеективними педагогічними умовами розвитку мотивації до моделювання військово-професійної орієнтації є: демонстрація важливості фоормування військово-профресійної орієнтації ліцеїстів під час опанування змісту загальноосвітньої та загальновійськової діяльності; активізація навчально-пізнавальної діяльності ліцеїстів; формування в ліцеїстів інтересу до військової діяльності; виховання в ліцеїстів переконаності щодо соціальної значущості військової профресії. Виявлено найбільш раціональний спосіб, що дозволяє вирішити проблему перевірки рівня достовірності експериментальних даних, че вивчення й аналіз подальшої військово-профресійної діяльності випускників. Основними показниками, що оцінювалися в даному разі, були вступ випускників ліцеїв до вищих військових навчальних закладів Збройних сил України й успішне опанування навчальної програми у процесі підготовки у вищих військових навчальних закладах.

Ключові слова: військово-профресійна оріентація, військовий ліцей, ліцеїст, вихованець, педагогічні умови, мотивація, навчально-пізнавальна діяльність, експеримент, резульmamu.
Problem statement. One of the important directions in reforming the Armed Forces of Ukraine is the development of a continuous military education system, including the provision of structural continuity from pre-professional education to higher military education. In contemporary conditions of lit- eral absence of basic military training in secondary schools, significant decrease in the number of youth military-patriotic camps, national-patriotic organisations for children, secondary education institutions of a military profile are an important source of professional military orientation for the young people who 
could further define their life and professional perspectives as subjects of professional military activity.

Recent research and publication analysis. The analysis and results of psychological and pedagogical sources demonstrate that various aspects of the issue of the youth's professional military orientation towards serving in the Armed Forces of Ukraine do not gain enough attention in academic researches by scholars and educational institution administrators. The problem of the young men's professional orientation towards military professions is dealt with in the works by V. Artemenko, H. Besarabchuk, A. Borysovskiy, V. Kovalskiy, M. Neschadym [1], L. Chernyshov, V. Chudnoy, V. Yahupov. Its content must include the following major tasks:

1. Modelling of motivation for future professional military activity.

2. Modelling of a citizen with a consciousness of Ukrainian people.

3. Developing a sense of loyalty and devotion to the people of Ukraine and the Oath of Allegiance.

4. Developing a sense of necessity to adhere to the demands of statutes, decrees and military discipline.

5. Modelling of a soldier's will, psychological perseverance, sense of dignity and readiness for the professional military activity etc [2, p. 159-160].

Their realisation directly influences the quality of the lyceum students' professional military orientation, promotes the modelling of motivation for future military service as well as gives a specific sense to their directedness towards the military profession. Various psychological aspects of personality directedness are studied by $\mathrm{O}$. Kovaliov, O. Leontiev, K. Platonov, V. Yahupov [3] and other scholars who define it as an element of personality motivational sphere.

From pedagogical perspective, the problem of personality directedness is studied by A. Aleksiuk, M. Tymchyk [4], L. Chupriy, and its professional orientation aspect - by V. Alfimova, I. Berestetska, V. Bobrov, H. Khmelnitskaya etc.

The analysis and generalisation of the results of the academic research by V. Alfimova, M. Bosenko, V. Borysova, H. Volyk, H. Khmelnitskaya and others show that a more purposeful psychological and pedagogical training of youth for military service as an officer takes place in military lyceums.

The aim of the article is an experimental testing of the pedagogical modelling of the professional military orientation (PMO) of the specialized military education institution students.

Presentation of basic material. The goal of the experiment was to test the effectiveness of pedagogical conditions for lyceum students' PMO. In order to achieve the goal established, the following objectives were defined and attained:

- to devise and substantiate a complex programme for effectivization of the PMO process based on its pedagogical modelling in lyceums;
- to define the possibilities for adjusting academic programmes with the purpose of implementing the complex of pedagogical conditions (influences and interactions) envisioned by the research and aimed at the effectivization of the military lyceum students' PMO;

- to conduct the pedagogical experiment;

- to analyse and generalise the results attained, to define the effectiveness of the activities for the military lyceums students' PMO.

The working hypothesis of the experiment lies in the assumption that achieving effectiveness of the lyceum students' PMO is possible via implementing respective pedagogical conditions, including its pedagogical modelling, military-patriotic education of lyceum students as a basis for the formation of motives and values of the future professional military activity as well as instilling in students the educational activity culture.

The pedagogical experimented conducted for testing the wording of the working hypothesis included two main stages: ascertaining and educational.

The ascertaining experiment was conducted with the purpose of pedagogical diagnosis of the lyceum students' PMO which objectively reflects the level of its formedness.

The educational experiment was conducted from 2017 through 2019. The objective of this stage was to form a complex of pedagogical measures which allow, with reasonable effectiveness, to influence the modelling of the students' $\mathrm{PMO}$, to study the dynamics of changes in the scales of its analysed components. 150 lyceum students were chosen and divided into control groups (CG) and experimental groups (EG) for the educational experiment. The basis for the experiment was formed by Luhansk regional lyceum with intensive military and physical training "Cadet Corps named in honour of the Young Guard heroes", Kamianets-Podilskyi lyceum with intensive military and physical training and Volodymyr Bezkorovainyi Naval lyceum.

In order to conduct the experiment, we devised a system of criteria and indicators for diagnosing its results according to which the effectiveness of the influence of the pedagogical conditions on the students' PMO is assessed. They are value-motivational, cognitive, behavioural-actional and subjective criteria.

The theoretical analysis of the problem under study, the experiment data and the students' experience of general military training suggest that one of the things that promote the students' $\mathrm{PMO}$ is the development of motivation for it.

The motives of the PMO modelling have a certain set of content-related and dynamic characteristics. Content-related characteristics mainly concern the internal peculiarities of professional military activity. Dynamic characteristics are not directly related to the 
internal peculiarities of professional military activity but rather depend on students' individual (including psychophysiological) peculiarities. It appears reasonable to consider the development of the students' motivation for the PMO formation to be a change in its content-related and dynamic characteristics in the process of establishment, reinforcement, stabilisation of motives and their subsequent qualitative improvement. Motivation development results in varying degrees of its formedness in young people at different stages of education.

Such is the mechanism for motivation forming, the knowledge of which allowed for the arrangement in the course of the experiment of purposeful work on the development of students' motivation for the formation of their professional military orientation. The work involved the execution of a set of pedagogical influence activities aimed at the consciousness, feelings and will of lyceum students and was intended to actualise those motives which insured the young men's active work on modelling their professional military activity.

The foundation of this work is constituted by the principal idea of the motivation formation mechanism, i.e. the lyceum students' comprehension of their own importance in professional military orientation modelling. The experiment results have showed that the most effective pedagogical conditions of motivation development are as follows:

- demonstration of the importance of the students' professional military orientation forming while mastering general educational and military activities;

- activisation of the students' learning and cognitive activity;

- formation of the students' interest to military activities;

- cultivation of the students' confidence in the social significance of the military profession.

The analysis of the experiment data indicates that the desire to be a well-rounded military expert is the strongest motive which encourages lyceum students to form professional military orientation. This is also attested by the opinion poll results in which $28 \%$ of the EC lyceum students ranked the given motive first among all others (professional and cognitive ones).

As the result of the activities conducted in accordance with the educational experiment programme, consistent motivation was cultivated in $37 \%$ of the EG lyceum students while the percentage of the CG students who reached the same level of motivation amounts to $18 \%$.

Since the process of professional military orientation modelling in students is polymotivated, epistemic motivation must be increased alongside the general military one. This was most promoted by the activisation of the lyceum students' learning and cognitive activities, in the process of which they acquired and developed such epistemic motives as the interest to solving various general military and general educational tasks, the desire to verify the level of their thinking, aspiration for self-development etc.

The most efficient methods and means for intensifying the students' learning and cognitive activities are: improving the content of the subjects studied; complex problem solving; asking problematic questions; demonstrating the lyceum students various methods of cognitive and mental activity; encouraging them to self-assess their level of thinking and providing assistance in selfdevelopment; providing lyceum students with individual tasks; preparing essays on future militaryprofessional activities, etc.

The purposeful analysis of the content, organisation and methodology of conducting different kinds of training sessions on different disciplines as well as interviews with all categories of the experiment participants allows to establish that the epistemic motivation of lyceum students is influenced by individual peculiarities of their thinking, collective opinion, attitudes, the classroom dynamics, the teacher's behaviour etc. Experiment data makes it possible to conclude that the intensity of learning and cognitive activity depends on the following factors:

1. Combination of collective and individual forms of the students' educational activity.

2. Establishment of a creative classroom atmosphere.

3. In addition to the creative atmosphere, it is necessary to maintain the students' collective positive emotional dynamics.

4. Timely encouragement of the students' initiative or creative manifestation is an essential factor of the emergence and development of cognitive motives in the process of studying.

The activation of the lyceum students' learning and cognitive activity, as discovered in the research, provides for simultaneous solving of two crucial tasks: first, to increase the students' epistemic motivation in respect to the mastery of general military and general educational thinking; second, to ensure deep knowledge acquisition and the development of general military skills necessary for successful addressing of the tasks set.

In order to research the dynamics of motivation development of the EG and CG at different stages of the experiment the measuring of lyceum students' motivation for the modelling of professional military orientation was conducted. This allows to make conclusions as to the effect motivation has on the modelling of the lyceum students' professional military orientation (see Table 1, fig. 1).

The acquired data demonstrate that in the EG, within which the intentional work on developing the motivation for the modelling of professional military orientation was made, the results of its levels are higher than in the CG. At the final stage the propor- 
tion of students with high motivation level amounts to $42,9 \%$ in the EG against $30,6 \%$ in the CG.

The development of the lyceum students' motivation for the modelling of professional military orientation was influenced by external and internal factors. The main external factors, as discovered in the research, are: the consistent management the of educational process and general military training, which includes immediate communication with higher military education institutions of the Armed Forces of Ukraine; positive examples of professional military activity set by the management and teaching staff of military lyceums; professional traditions, opinions among lyceum students, their attitudes toward future military activity etc.

The most significant internal motivational factors included: the desire for mastery of general military knowledge, the understanding of importance of general military training for future service, the objectivity of the lyceum student's self-evaluation of the formedness level of general military knowledge and skills.

Therefore, according to the conclusions of the experiment, the development of lyceum students' motivation for the modelling of the professional military orientation is one of the ways of the effectivization of their general military training.

For the purpose of qualitative and quantitative comparative assessment, the grading scale of indicators of the lyceum students' PMO levels was imple- mented during the experiment. The scale was represented with points from 2 to 5 whereby:

- 5 points: students have a well-formed steady system of values and motivations, they recognise goals and tasks of their activity;

- 4 points: students generally have formed the system of values and motivations, they generally recognise goals and tasks of their activity;

-3 points: the system of values and motivations, the idea of goals and tasks of the future military activity are at the stage of formation; knowledge and skills are below the necessary level;

- 2 points: motives, needs, values and goals are beyond the necessary PMO sphere, the obtained knowledge functions predominantly at the level of memorizing, skills are not formed.

The assessment in accordance with the corresponding criteria was represented in the form of an overall grade consolidated on the basis the of assessment of particular scales.

After data processing, we outlined the formedness levels of the lyceum students' general educational competence or key fundamentals of primary general military competence taking into consideration the ranking results, which was divided into high, medium, critical and unsatisfactory levels.

The main results acquired in the course of the experiment are presented in table 2 . While analysing the dynamics of the PMO formation in lyceum stu-

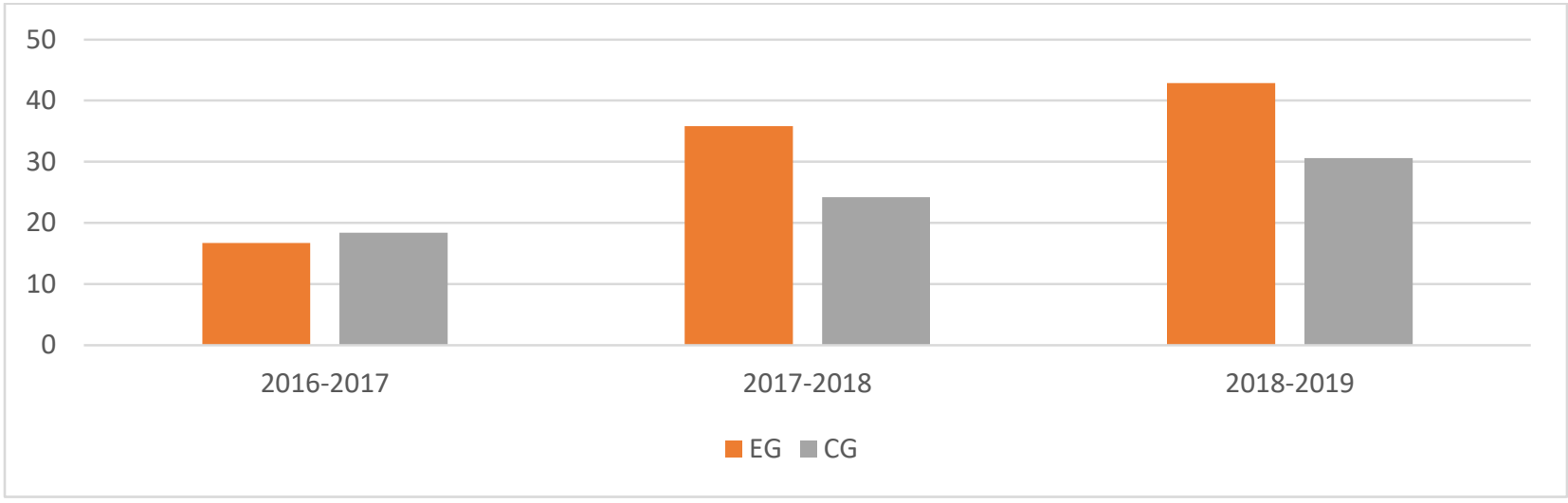

Fig. 1. Proportion of lyceum students with high motivation level (in \%)

Table 1

The lyceum students' motivation for the modelling of professional military orientation in EG and CG

\begin{tabular}{|c|c|c|c|c|}
\hline \multirow{2}{*}{ Measurements } & Groups & \multicolumn{2}{|c|}{$\begin{array}{c}\text { Number of lyceum students (in \%) with different level } \\
\text { of the formedness of the motivation for the modelling } \\
\text { of professional military orientation }\end{array}$} \\
\hline & & High & Medium & Low \\
\hline I (2016-2017 yrs.) & experimental & $\mathbf{1 6 , 7}$ & $\mathbf{6 1 , 9}$ & $\mathbf{2 1 , 4}$ \\
\hline & control & 18,4 & 63,6 & 18,0 \\
\hline II (2017-2018 yrs.) & experimental & $\mathbf{3 5 , 8}$ & $\mathbf{5 8 , 7}$ & $\mathbf{5 , 5}$ \\
\hline & control & 24,2 & 52,7 & 23,1 \\
\hline III (2018-2019 yrs.) & experimental & $\mathbf{4 2 , 9}$ & $\mathbf{5 3 , 8}$ & $\mathbf{3 , 3}$ \\
\hline & control & 30,6 & 47,4 & 22,0 \\
\hline
\end{tabular}


Lyceum students' PMO formation levels (in \%)

\begin{tabular}{|c|l|c|c|c|c|c|c|}
\hline \multirow{2}{*}{ № } & \multirow{2}{*}{ PMO formation levels } & \multicolumn{2}{|c|}{ I assessment } & \multicolumn{2}{|c|}{ II assessment } & \multicolumn{2}{|c|}{ III assessment } \\
\cline { 3 - 8 } & & CG & EG & CG & EG & CG & EG \\
\hline A & High & 10 & $\mathbf{1 5}$ & 10 & $\mathbf{2 0}$ & 14 & $\mathbf{2 7}$ \\
\hline B & Medium & 44 & $\mathbf{4 0}$ & 42 & $\mathbf{5 2}$ & 41 & $\mathbf{5 6}$ \\
\hline C & Critical & 42 & $\mathbf{3 6}$ & 39 & $\mathbf{2 5}$ & 34 & $\mathbf{1 4}$ \\
\hline D & Unsatisfactory & 4 & $\mathbf{9}$ & 9 & $\mathbf{3}$ & 11 & $\mathbf{3}$ \\
\hline
\end{tabular}

dents who reached its highest level (see Table 2, A) with each subsequent assessment one observes a sustained growth in the number of the EG students who attained a positive result. This gives grounds to the suppositions that further analysis of the PMO formation dynamics is reasonable. In addition, this conclusion is sustained by the fact that the initial PMO levels of the EG and CG students were reasonably identical and did not have any statistically significant difference. The results of the first assessment confirm the positive conclusion as to the implementation of the respective pedagogical conditions. The percentage ratio of the students according to the high, medium, critical, or low PMO formation level is approximately the same in the EG and CG which allowed for the consideration of the acquired results with certainty as to their objectivity and aptitude for suppositions concerning the research hypothesis.

The tendency of the PMO formation level increase on the basis of the activity analysis of the EG students who reached the medium level is also evident. However, the results of the first assessment indicate the raise of the percentage ratio of the students with medium PMO formation level in the CG as opposed to the EG. This fact suggests that in order to obtain practical results a certain time period is required for young men to adjust to new studying conditions.

An important factor which lowers the research results at the initial level is the insufficient coordination of activities for the realisation of the pedagogical conditions for the PMO formation, their insufficient methodical level.

The distinguishing feature of the PMO formation dynamics at the medium level (see Table 2, B) is the declination of the number of students reaching it, which is identified in the process of the second and third assessments.

The analysis of the acquired data demonstrates that the main reasons for this are as follows:

1) the lyceum graduates' voluntary refusal to enter an HMEl which is on concessional terms for them; the results of opinion polls show that it is the part of students who intentionally decided to do so;

2) several students' transfer to a lower level because of the difficulties occurring with the gradual complication of the lyceum training programmes;

3) expulsion of students reasoned by their disappointment in career choice (during control research it appeared to be also true for military HEIs);
4) expulsion of students because of the unsatisfactory (psychological) results of their learning activity in the lyceum.

Pedagogical conditions are as well designed for the individualisation of the educational process, formation of the self-formation qualities of the students' personality, stimulation of creativity and initiative in the learning activity and give reasonable results. Thus, the increase in the number of students with medium level of the PMO formedness in the EG (see Table 2, B) is rather dynamic and fully compensates for the number of the expelled lyceum students who studied in the groups given.

The students with a critical level of the PMO formedness as to the results of the first assessment were viewed as a basis for increasing the number of students with its medium level. As reflected in the first assessment (see Table 2, C), the number of students with a critical level in the EG and CG differs insignificantly. After the second assessment some significant changes occur. Students who failed to maintain the medium level joined the ranks of the those falling behind in the CG whereas in the EG, contrariwise, the number of students with a critical PMO level decreased at the account of transfer to the medium level.

During the third assessment, a positive result is observed in both groups, although the rates are higher in the EG.

The consideration of the dynamics of the influence of pedagogical conditions on the PMO of the lyceum students with an unsatisfactory level of its formation is also of certain research interest. A particular cause for concern was the fact that as a result of the first assessment (see Table 2, D) the number of students falling behind in the EG surpassed the respective indicator in the CG almost by three times. Arguments were needed in order to make a conclusion. The main but unpleasant one is that the conditions of the experiment do not fully contribute to the establishment of an environment suitable for the PMO formation in students with low potential. It is quite probable that not all PMO formation factors were taken into account.

The results of the second and third assessments elicited the following consistent pattern: in the EG, the number of students falling behind is reduced at the account of the expulsed ones whereas the transfer to a higher level is rather insignificant. 
The analysis of the acquired experimental results allows to make a conclusion that it is necessary to prepare an active and creative personality in military lyceums. However, not all the students appear to be individually and psychologically ready since some do not have a sufficient general education background which must be entirely formed at school whereas others are not psychologically ready.

The programme complication at the second year of studies led to an increase in the number of the lyceum students falling behind in the CG. The fact that according to the results of the second and third assessments this number is approximately the same while not comprising the same people has conditioned the termination of the analysis of the PMO formation dynamics within the given category of students.

As it was envisioned, the final stage of the experiment, the criterion of the validity of the data acquired in the its process, the objectivity of suppositions as to the students' PMO formation dynamics, was to be the results of the military lyceum graduates' practical realisation of the formed qualities which define their behaviour and subsequent professional career. In our opinion, the most rational way to solve the issue of verification of the data validity level is the study and analysis of the graduates' subsequent professional military activity. The principal indicators evaluated in this case were the following:

- the lyceum graduates' enrolment into an HMEI of the Armed Forces of Ukraine (fig. 2);
- the successful mastery of the educational programmes during studying in a HMEI (fig. 3).

In this case, the comparison of the EG and CG results is conducted by means of grouping based on four-point scale grades. This provided for the verification of the credibility of the results acquired in the process of the research. The results of students who reached the highest PMO level are intercompared with the subsequent assessments of their general military and general education activity.

The comparative analysis of the experiment results enables us to conclude that the EG results are significantly better than the respective CG results. This particular factor proved to be the most substantial. The entrance results of the lyceum graduates with a high PMO level are significantly better compared to the results obtained by the students placed in other groups as a result of the experiment.

Furthermore, such control scales as the military lyceum graduates' enrolment into higher military education establishments and their successful mastery of the training programme are instantly dependent on the students' PMO level during the studies in the specialised secondary education establishments of a military profile. Thus, the results indicate that $88 \%$ of lyceum graduates experimentally defined as having reached a high PMO level have entered an HMEl.

The graduates of Luhanks regional lyceum with intense military and physical training "Cadet Corps named in honour of the Young Guard heroes",

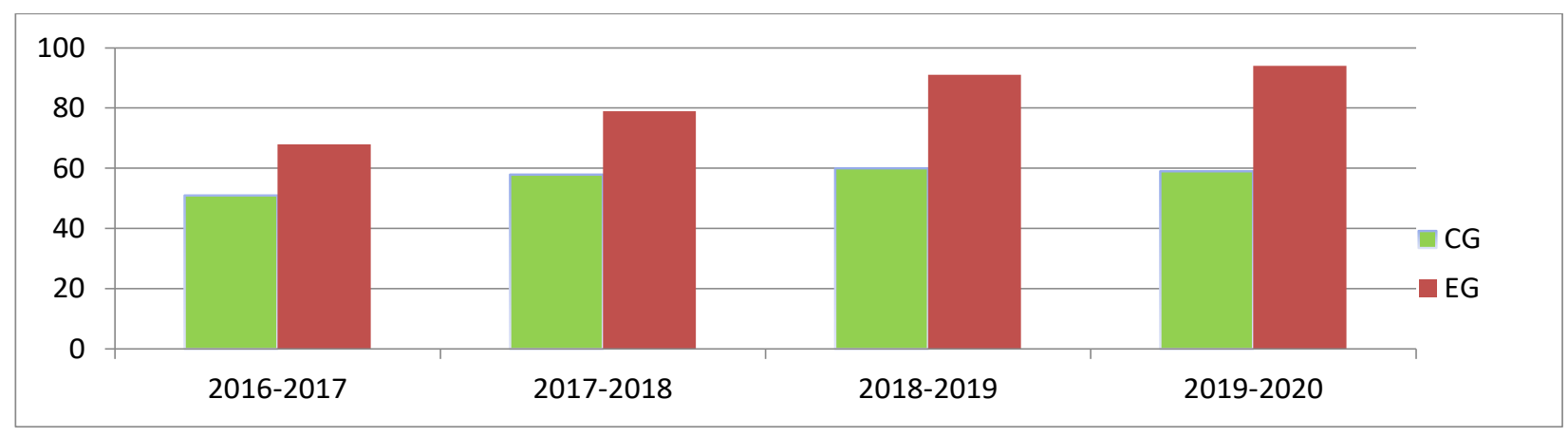

Fig. 2. Dynamics of the lyceum graduates' enrolment into an HMEI of the AF of Ukraine (in \%), the authors' development

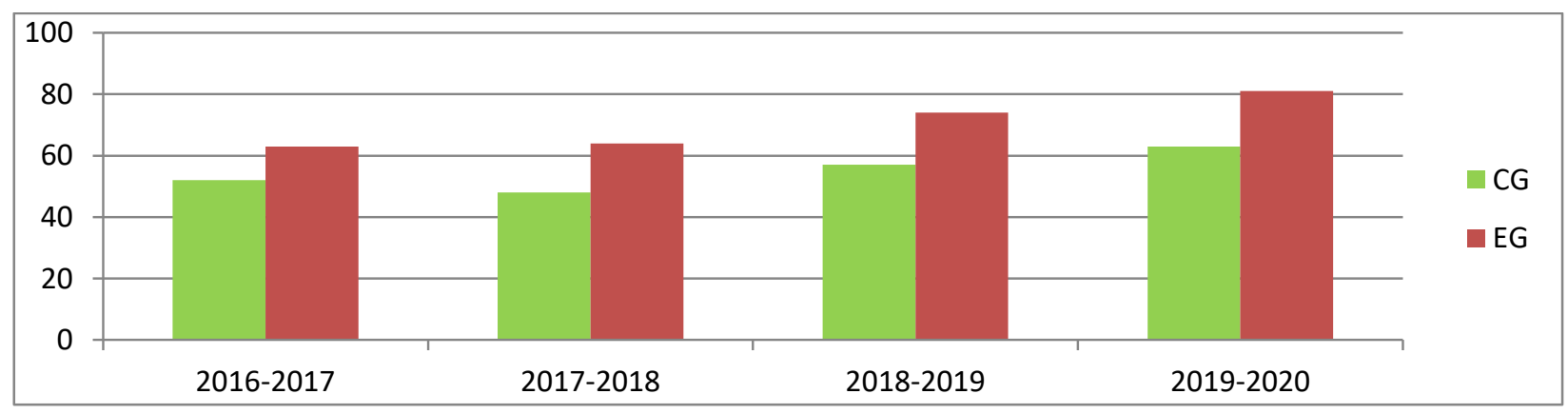

Fig. 3. Dynamics of the military lyceum graduates' successful mastery of the HMEI educational programme (in \%), the authors' development 
Kamianets-Podilskyi lyceum with intense military and physical training and Volodymyr Bezkorovainyi naval lyceum who have a medium PMO level and have been admitted to HMEl constitute 57\%. Correspondingly, the percentage of students with a critical or unsatisfactory PMO level entering higher military education establishments amounts to 43 and 31\%.

More than $70 \%$ of military lyceum graduates evaluated in the experiment as those with high and medium PMO levels successfully master the higher military school programme. At the same time, only $8-10 \%$ of graduates with an unsatisfactory PMO level successfully master the HMEI programme.

Therefore, the results of the analysis of the control scales of the assessment of the lyceum students' PMO pedagogical conditions allow to consider them to be the factors that substantiate the validity of the experiment results. The conducted experiment shows that PMO is a complex and durational process determined by the influence of a set of goaloriented and interrelated pedagogical conditions. In our opinion, the diagnosis criteria and indicators have provided for a reasonably objective identification of the students' PMO level at the corresponding stages of study. In its turn, this has allowed for the implementation of the necessary adjustments to the pedagogical process as to the lyceum students' PMO development.

The results of the educational experiment have justified the accuracy of the research hypothesis and allowed to determine the major pedagogical conditions of the lyceum students' PMO formation.

\section{REFERENCES:}

1. Neshchadym M. Military education of Ukraine: history, theory, methodology, practice : Monograph. Kiev, Ukraine : University of Kiev, 2003. 852 p.

2. Yagupov V. Military education : history, theory and methodology. Kyiv, Ukraine, 2002. 560 p.

3. Yagupov V. Military Psychology : Textbook. Kyiv : Tandem, 2004. 649 p.

4. Tymchyk $M$. Patriotic education of older adolescents in the process of physical culture and mass work : Dis. ... for Candidate of Pedagogical Sciences. Kyiv, 2012. 222 p. 